\title{
Design Of Modified Microstrip Antenna And 4x1 Microstrip Array For Data Communication
}

\section{At $2.4 \mathrm{GHz}$ Frequency}

\author{
Koko Joni ${ }^{1}$, Haryanto ${ }^{2}$, Silviana Nur Azizah ${ }^{3}$ \\ Electrical Engineering Department \\ Trunojoyo University of Madura \\ Bangkalan, Madura \\ ${ }^{1}$ kokojoni@gmail.com, ${ }^{2}$ haryanto_utm@yahoo.com, ${ }^{3}$ silviananur676@yahoo.com
}

\begin{abstract}
The use of wireless or wireless communication technology is currently growing rapidly. To establish a wireless communication device, an antenna is needed to send and receive electromagnetic waves or signals during the data transmission process. In this research we undertook simulation, fabrication, parameter and distance testing for data communication at $2.4 \mathrm{GHz}$ frequency. To achieve the above objective, first we made an antenna.TThe antenna dimensions were designed based on antenna formulas and then simulating with the CST Studio Suite. Second, we fabricated Microstrip antennas senders that could work well in the $2.4 \mathrm{GHz}$ frequency with return loss $=\mathbf{- 1 2 . 0 6} \mathrm{dB}$, VSWR $=1.692$, impedance $=38.35 \Omega$ ohms. While the $4 \times 1$ fabricated microstrip array antenna was designed to operate at 2.4 GHz frequency with return loss $=\mathbf{- 1 9 . 4 1} \mathrm{dB}, \mathrm{VSWR}=\mathbf{1 . 2 3 5}$, impedance $=54.77 \mathrm{ohms}$. That is, the two microstrip antennas are suitable for use at $2.4 \mathrm{GHz}$ frequency and in accordance with the expected specifications. The test using module Xbee PRO S2C and Xbee S2C . Result showed that communication runs smoothly that is able to send and received data properly.
\end{abstract}

Keywords —antenna; return loss; impedance, distance

\section{INTRODUCTION}

The use of wireless or wireless communication technology is currently growing very rapidly. To do wireless communication, an antenna is needed because it functions to send and receive electromagnetic signal waves. In data communication between 2 antennas, an RF (Radio Frequency) module is needed. This data communication test is to determine the distance of the antenna range that is fabricated as a signal amplifier and analyze the telemetry performance system.

Telemetry is a communication system for the transfer of remote measurement data that uses transmission media as a data carrier. In other words, it can be said that telemetry is an automatic communication process that is used to measure and retrieve data at a location that is far away to be transmitted to the data processing center [1]. Telemetry sistem influnce by antenna wehere proper antenna selection, good design and correct installation will guarantee the performance of the system. The problem that often occurs is that the transceiver antenna cannot work optimally for a considerable distance.

In this study is designed, simulation, fabrication, antenna parameter testing using VNA (Vector Network Analyzer) and antenna range test. Single patch microstrip antennas that are modified to obtain omnidirectional radiation patterns are recommended as sending antennas because they are easy to manufacture, inexpensive, small and light dimensions so that they are suitable to be applied on a moving device [2]. While yagi antennas and 4x1 microstrip array antennas (have more patches) are chosen as the receiving antenna for comparison because they are equally directional, which means the direction of the beam is focused in one direction and tends to have a large gain compared to omnidirectional so that it can receive signals with a sufficient distance range in a loss condition (without obstruction) if it is focused on the sending antenna.

In the previous research conducted by Alam, et al [3], in his journal entitled "Rancang Bangun Antenna Mikrostrip Peripheral Slits Linear Array Untuk Aplikasi Wi-Fi (Building Design of Peripheral Microstrip Antenna Linear Array for WiFi Applications)". The measurement results of the composition of the four elements of peripheral slits obtained a bandwidth of $150 \mathrm{MHz}(2.424 \mathrm{GHz}-2.574 \mathrm{GHz})$ with a percentage of bandwidth of $6.12 \%$. Measurement results at the middle frequency of $2.448 \mathrm{GHz}$ obtained a return loss of $-16.88 \mathrm{~dB}$ with a VSWR of 1.304.

Pasaribu, et al [4] on his journal entitled "Rancang Bangun Antena Mikrostrip Patch Segiempat Pada Frekuensi 2, 4 Ghz Dengan Metode Pencatuan Inset (Design of Patch Rectangular Microstrip Antenna at Frequency of 2, $4 \mathrm{Ghz}$ with the Inset Imaging Method)". Based on the results of the antenna bandwidth obtained at $112 \mathrm{MHz}(2.388-2.5 \mathrm{GHz})$ in VSWR $\leq$ 2. At the middle frequency of the antenna $(2.45 \mathrm{GHz})$ obtained return loss of $-14.77 \mathrm{~dB}$, VSWR of 1.45 , radiation pattern unidirectional, and gain $6 \mathrm{dBi}$

Joni, et al [5] entitled "Pengujian Jarak dan Waktu Gabung Protokol IEEE 802.15. 4 / ZigBee di Lingkungan Indoor (Protocol IEEE 802.15. 4 / ZigBee Distance Test and Join Time in the Indoor Environmen)." The results showed that the pairing method can be done long distances to the outside of the building with a distance of about 65 meters, while the distance using the On / Off method can reach several rooms in the indoor area. The longest time to join takes about 1 minute 15 seconds . 
According to Qun, Deng Et al [9]. "Design and simulation of the microstrip antenna for 2,4 Ghz HM remote control system", showed that antenna model simulated in ADS and obtained the requirement parameter thrrough optimizing and matching.

\section{THEORY}

\section{A. Microstrip Antenna}

Based on the origin of the word, microstrip consists of two words, namely micro (very thin / small) and strip (slats / pieces). Microstrip antennas can be defined as one type of antenna that has a shape like a blade or a piece that has a very thin or small size[2].

\section{B. Dimensions of the Microrip antenna}

In designing a microstrip antenna using CST Studio Suite 2016 software, the antenna dimensions are determined in advance based on the calculation of the antenna formula. The frequency and specifications of the material to be used are the main factors in the calculation of antenna dimensions.

The basic structure of a microstrip antenna consists of a radiating element or commonly called an conducting patch, substrate element (dielectric substrate), and grounding element. The size of the irradiation or patch element is obtained from the following equation [2]:

Patch width (W) can be calculated by the equation [2] :

$$
W=\frac{C}{2 f_{0} \sqrt{\frac{\left(\varepsilon_{r}+1\right)}{2}}}
$$

$$
\begin{aligned}
& \mathrm{W}=\text { patch wide }(\mathrm{mm}) \\
& \mathrm{c}=\text { Light speed }(3 \mathrm{x} \llbracket 10 \rrbracket \wedge 8 \mathrm{~m} / \mathrm{s}) \\
& \mathrm{f} \_0=\text { Resonance Frekuency }(\mathrm{Hz}) \\
& \varepsilon \_r=\text { permittivity } / \text { constant dielectric }
\end{aligned}
$$

Whereas Patch Length (L) can be calculated by the equation [2] :

$$
W=\frac{C}{2 f_{0} \sqrt{\frac{\left(\varepsilon_{r}+1\right)}{2}}}
$$
equation:

Where is the effective length obtained from the

$$
L_{e f f}=\frac{c}{2 f_{0} \sqrt{\varepsilon_{r_{e f f}}}}
$$

In calculating $L_{e f f}$ it must be known $\varepsilon_{r_{e f f}}$ For $\varepsilon_{r_{e f f}}$ can be calculated by the equation[2] :

$$
\varepsilon_{r_{e f f}}=\frac{\varepsilon_{r}+1}{2}+\left(\frac{\varepsilon_{r}-1}{2} x \frac{1}{\sqrt{1+\left(\frac{12 h}{W}\right)}}\right)
$$

And for increasing length $(\Delta L)$ can be calculated by the equation [2] :

$$
\Delta L=0,412 \cdot h \frac{\left(\varepsilon_{r_{e f f}}+0,3\right)\left(\frac{W}{h}+0,264\right)}{\left(\varepsilon_{r_{e f f}}-0,258\right)\left(\frac{W}{h}+0,8\right)}
$$

Next look for the dimensions of the feeder (transmission line). Feeder width (Wf) can be calculated by the equation [6]:

$$
B=\frac{60 \pi 2}{Z \sqrt{\varepsilon_{r}}}
$$

$$
\begin{aligned}
& W f=\frac{2 h}{\pi}\{(B-1-\ln (2 B-1))\}+\frac{\varepsilon_{r}-1}{2 \varepsilon_{r}}\{(\ln B-1)+ \\
& \left.0.39-\frac{0.61}{\varepsilon_{r}}\right\}
\end{aligned}
$$

While the length of the feeder (Lf) can be written with the equation [6]:

$$
\begin{gathered}
\Delta \mathrm{g}=\frac{\lambda}{\sqrt{\varepsilon_{r_{e f f}}}} \\
L s=\frac{1}{4} \lambda
\end{gathered}
$$

Next look for groundplane dimensions. The groundplane on the microstrip antenna serves to separate the dielectric substrate from other objects that can interfere with signal radiation.

Groundplane Width Dimensions (Wg) can be calculated by the equation [7] :

$$
\mathrm{Wg}=6 \mathrm{~h}+\mathrm{W}
$$

As for the groundplane length $(\mathrm{Lg})$ can be calculated by the equation:

$$
\operatorname{Lg}=6 h+L
$$

The distance between the elements on this antenna is $\lambda / 2$ with a constan [2]

$$
\lambda=\frac{c}{f}
$$

Required specifications

TABLE I. MATERIAL ANTENNA SPECIFICATION

\begin{tabular}{|l|l|l|}
\hline \multirow{2}{*}{ Copper } & \multicolumn{2}{|c|}{ Spesification } \\
\cline { 2 - 3 } & \multicolumn{1}{|c|}{$\begin{array}{c}\text { Relative Permitivity } \\
\left(\boldsymbol{\varepsilon}_{r}\right)\end{array}$} & \multicolumn{1}{c|}{ Thickness } \\
\hline Copper & 1 & $0,035 \mathrm{~mm}$ \\
\hline $\begin{array}{l}\text { FR4 Epoxy } \\
\text { (substrate) }\end{array}$ & 4,3 & $1,6 \mathrm{~mm}$ \\
\hline
\end{tabular}


TABLE II.

ANTENNA SPECIFICATION PARAMETER

\begin{tabular}{|l|l|}
\hline \multicolumn{1}{|c|}{ Parameter } & \multicolumn{1}{c|}{ Value } \\
\hline Frequenzy & $2,4 \mathrm{GHz}$ \\
\hline Strenght & $<-10 \mathrm{db}$ \\
\hline Return Loss & $<2$ \\
\hline VSWR & $50 \mathrm{Ohm}$ \\
\hline
\end{tabular}

Table II Material that used to make antenna with required parameter at Table II.

\section{Techniques For Microstrip Antenna Recording}

The feed technique used is the Microstrip line feed technique. This technique is one popular, simple and easily fabricated technique is a line feed technique, but this technique results in a bandwidth that is not wide and the gain is not so large [8].

\section{RESEARCH METHODS}

\section{A. Flowchart}

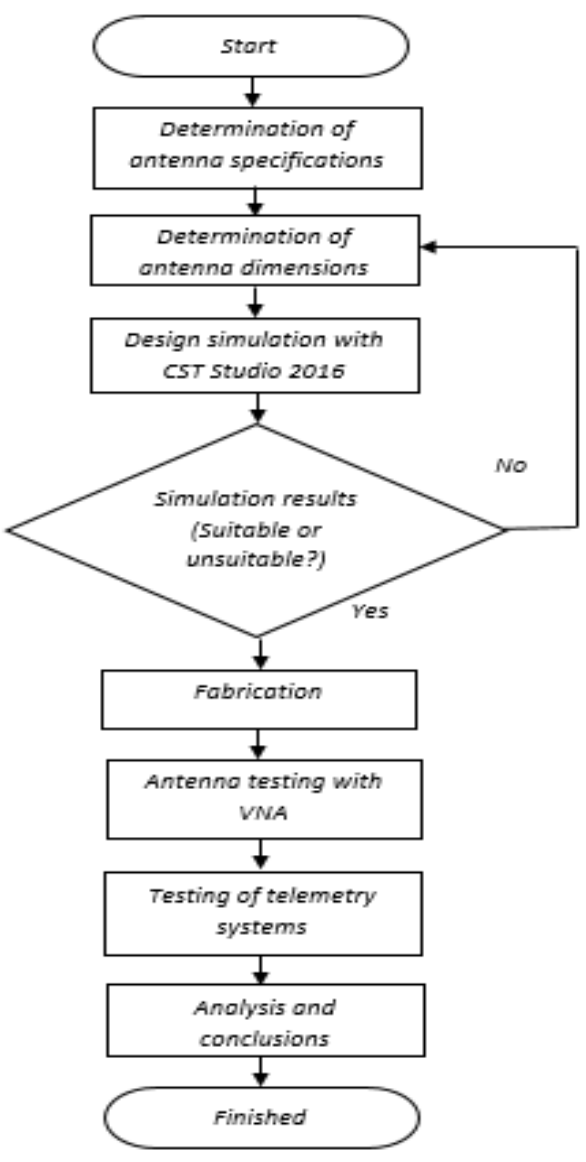

Fig. 1. Flowchart

The initial stage of the research is to study literature about the antenna to be made. Determine the required material specifications and antenna parameters and the dimensions of the antenna based on the antenna formula. Then design by entering the dimensions and simulating the CST Studio Suite 2016. software simulation results in the form of antenna parameters that affect the performance of the antenna (Fig 1). The parameters taken as a reference here are the matching parameters, namely VSWR, Return Loss and impedance. If the simulation results are not in accordance with the expected antenna specifications, it is necessary to optimize the simulation by changing the antenna dimensions slightly and modifying the shape. If the simulation results are appropriate, then fabricated and tested for feasibility with a VNA device. After this stage, direct distance testing or telemetry system implementation is carried out.

\section{B. Telemetry System Block Systems}

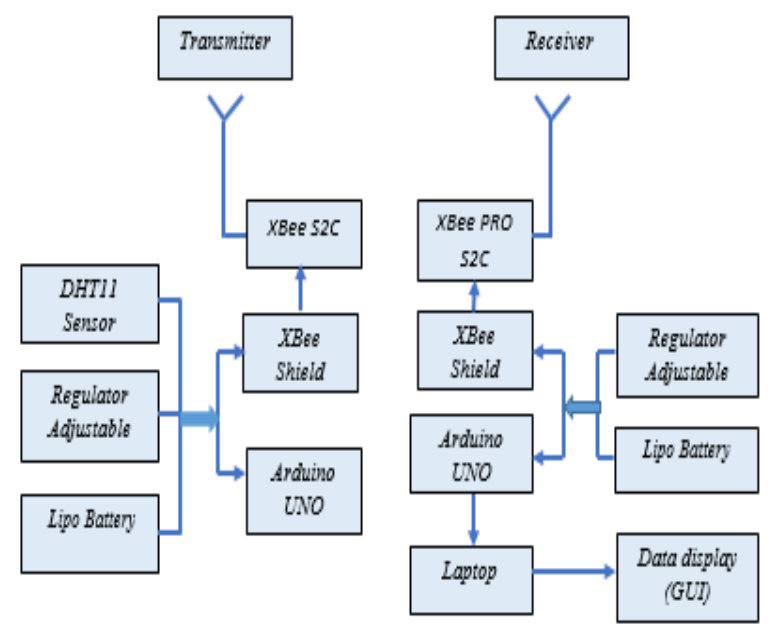

Fig. 2. Telemetry System Block Diagram

The working principle of this telemetry system is sending data in the form of temperature using a DHT11 sensor, then processing the data by Arduino. In this telemetry system lipo batteries are used as a voltage source and adjustable regulator as a voltage regulator / stabilizer. The transmitter and receiver modules used are Xbee modules that work on the $2.4 \mathrm{GHz}$ frequency. Modified microstrip antennas are used as sending antennas, while receiver antennas are used microstrip array antennas installed in GCS (Ground Control Station) and connected to laptops. The test can determine the maximum range of the antenna can send or receive signals

\section{RESULT AND DISCUSSION}

\section{A. Sender Microstrip Antenna}

The designed sender microstrip antenna is expected to have an omnidirectional radiation pattern. Therefore, at least 2 substrates must be needed, namely FR4 Epoxy double layer and single layer. The patch model that is designed is rectangular then modified by adding parasitic and adjusting the antenna dimensions.

The following is an optimized table of antenna dimension calculation. 
TABLE III. OPTIMIZED SENDER MICROSTRIP DIMENSIONS

\begin{tabular}{|l|l|}
\hline \multicolumn{1}{|c|}{ Antenna Dimension } & Value (mm) \\
\hline Patch Width (W) & 40 \\
\hline Patch Length (L) & 34 \\
\hline Gpf & 0,2 \\
\hline patch feeder width (Wf) & 1,404 \\
\hline patch feeder length(Lf) & 15 \\
\hline Patch radius & 8 \\
\hline Substrate width (Ws) & 47 \\
\hline substrat length (Ls) & 80 \\
\hline ground width (Wg) & 22 \\
\hline ground length (Lg) & 40 \\
\hline feeder ground width (Wfg) & 3,038 \\
\hline feeder ground length (Lfg) & 40 \\
\hline Slot radius & 12 \\
\hline
\end{tabular}

\section{1) Simulation Test}

Antenna works well at a frequency of $2.4 \mathrm{GHz}$ with return loss $=-33.45 \mathrm{~dB}, \mathrm{VSWR}=1.043$, impedance $=50 \mathrm{ohm}$, gain $=$ $2.207 \mathrm{~dB}$. This antenna is expected to have an omnidirectional radiation pattern (emission in all directions) because it will be applied as a sending antenna, but the simulation results of this antenna are still bidirectional radiation pattern (two-way beam). The parameter simulation results are shown in Fig 3,4,5,6.

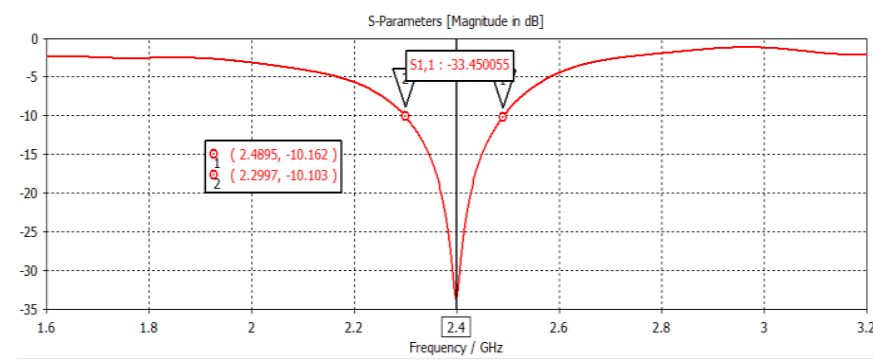

Fig. 3. Return Loss Simulation Results of Sender Microstrip Antenna

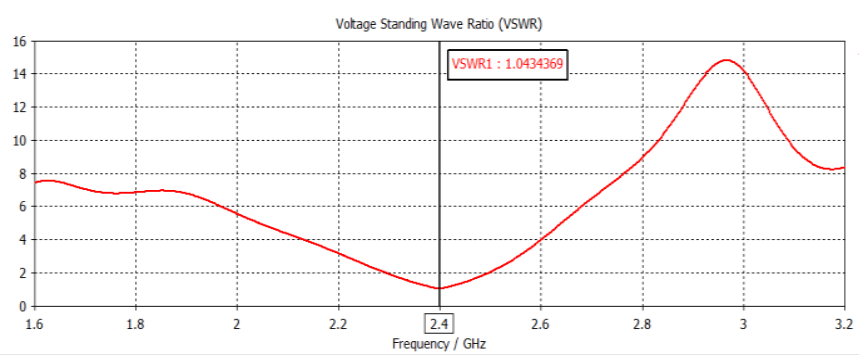

Fig. 4. VSWR Simulation Results of Sender Microstrip Antenna

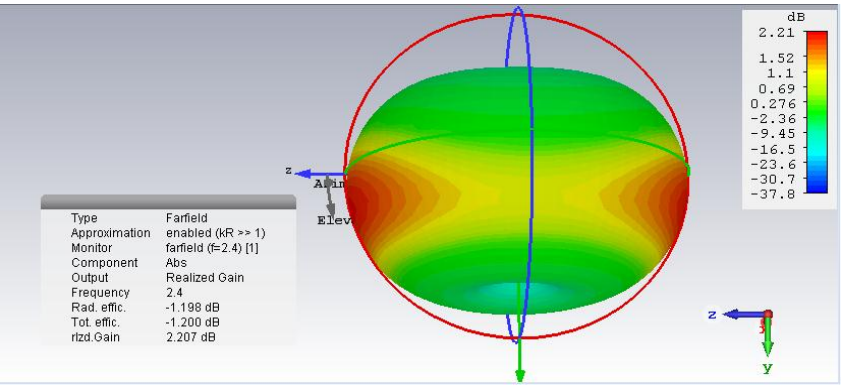

Fig. 5. Gain Simulation Results of Sender Microstrip Antenna

Farfield Realized Gain Abs (Azimuth $=90$ )

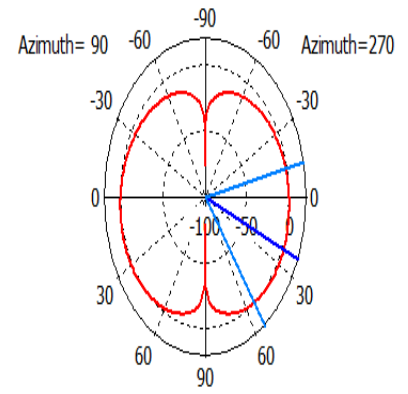

Elevation / Degree vs. dB
Frequency $=2.4$

Main lobe magnitude $=1.02 \mathrm{~dB}$ Main lobe direction $=23.0 \mathrm{deg}$. Angular width $(3 \mathrm{~dB})=66.4 \mathrm{deg}$.
Fig. 6. Results of Simulation of Sender Microstrip Antenna Radiation Pattern

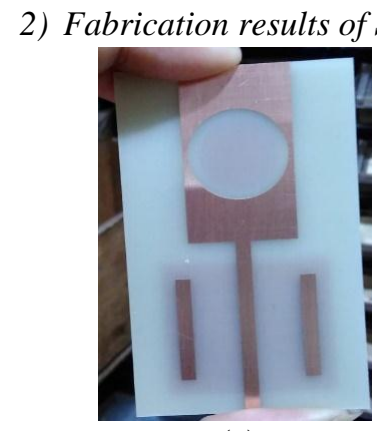

(a)

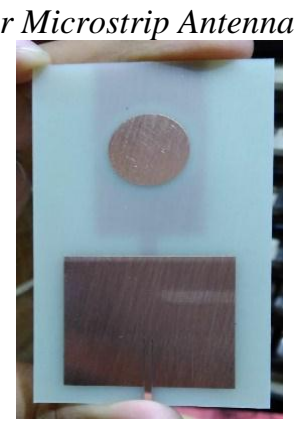

(b)
Fig. 7. (a) Sending Microstrip antenna front and rear with 2 substrates(b) Sending Microstrip Antenna patch parts

\section{3) Sending Microstrip Antenna patch parts}

The fabricated sender microstrip antenna is able to work at $2.4 \mathrm{GHz}$ frequency with return loss $=-12.06 \mathrm{~dB}, \mathrm{VSWR}=1.692$, impedance $=38.35 \square \square 24,70$. This means that the antenna that is fabricated is in accordance with the expected specifications. But for impedance does not match the cable impedance used is the RG58 $50 \square$ coaxial cable. Bandwidth or working area of this antenna is $282 \mathrm{MHz}$ between the frequency of $2,298 \mathrm{GHz}$ 2,580 GHz. Test results with VNA are shown in Fig 8,9,10. 


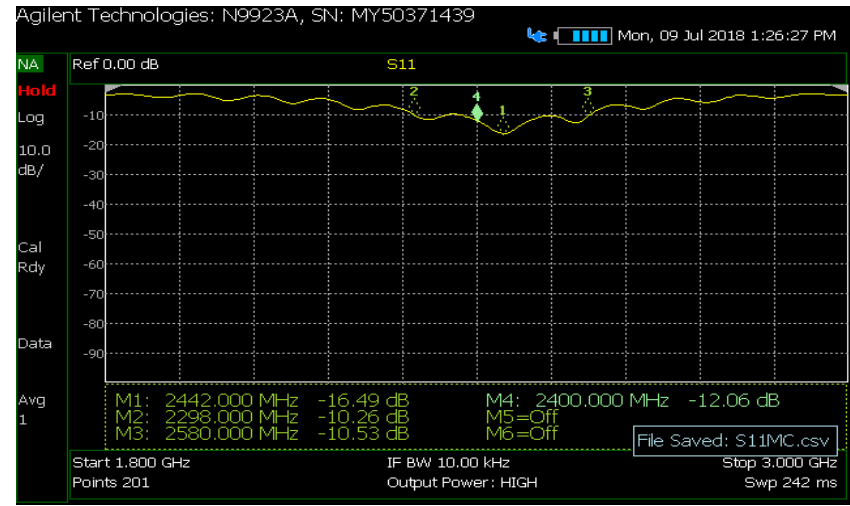

Fig. 8. Results of Return Loss Testing with VNA in Sender Microstrip Antenna

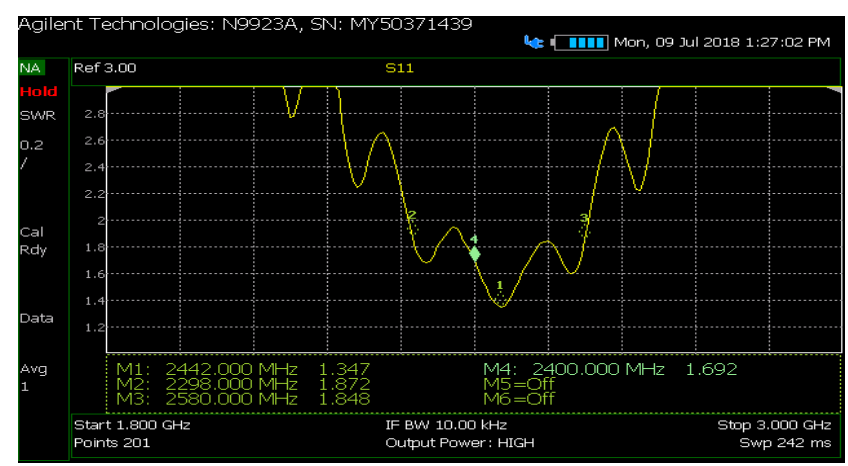

Fig. 9. Results of VSWR Testing with VNA in Sender Microstrip Antenna

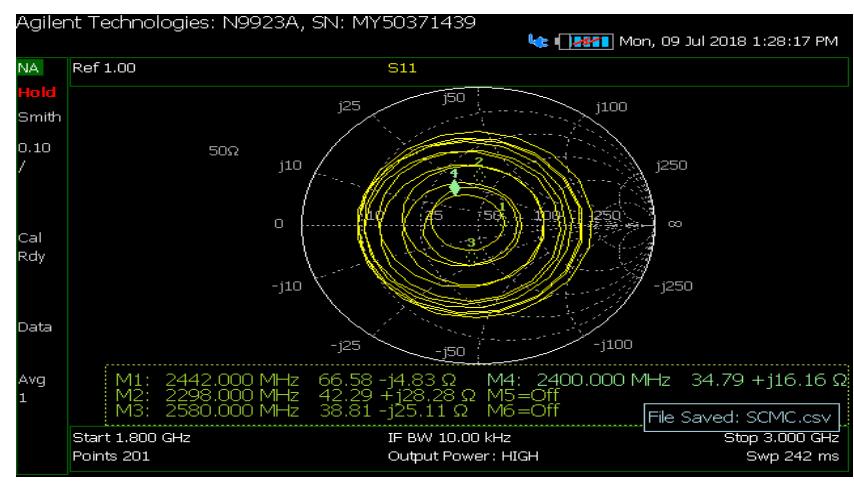

Fig. 10. Results of Impedance Testing with VNA in Sender Microstrip Antenna

\section{B. $4 x 1$ Array Microstrip Antenna}

The designed $4 \times 1$ microstrip array antenna is applied to the receiver side in GCS (Ground Control Station) and is expected to have unidirectional radiation patterns.

The following is a table resulting from the calculation of the antenna dimensions that have been optimized.

TABLE IV. DIMENSIONS OF ARRAY ANTENNAS THAT HAVE BEEN OPTIMIZED

\begin{tabular}{|l|c|}
\hline \multicolumn{1}{|c|}{ Antenna Dimension } & Value (mm) \\
\hline Patch Length (L) & 38 \\
\hline Lebar Width (W) & 29 \\
\hline Inset Length (Li) & 8,85 \\
\hline
\end{tabular}

\begin{tabular}{|l|c|}
\hline \multicolumn{1}{|c|}{ Antenna Dimension } & Value (mm) \\
\hline Inset Widt (Gpf) & 1 \\
\hline Feeder Widt (Wf) $50 \Omega$ & 3,137 \\
\hline Feeder Widt (Wf) $70 \Omega$ & 1,677 \\
\hline Substrat Length \& Ground (Lsg) & 315 \\
\hline Substrat Widt \& Ground (Wsg) & 80,51 \\
\hline Distance Patch 1\&2 & 35 \\
\hline Distance Patch 2\&3 & 62,5 \\
\hline Distance Patch 3\&4 & 35 \\
\hline
\end{tabular}

\section{1) Simulation Testing}

Antenna works at $2.4 \mathrm{GHz}$ frequency with return loss of $50.44 \mathrm{~dB}$, VSWR of 1.035, impedance of $49 \mathrm{ohms}$, and gain of $6.362 \mathrm{~dB}$ and has a directional radiation pattern. The parameter simulation results are shown in Fig 11,12,13,14.

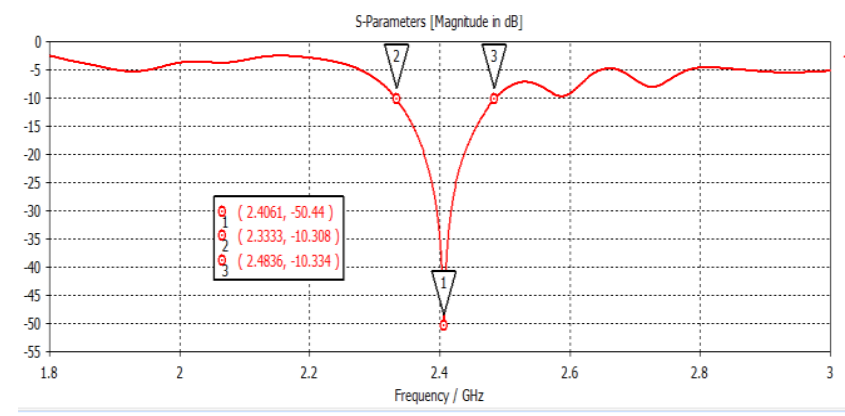

Fig. 11. Return Loss Simulation Results of 4x1 Array Microstrip Antenna

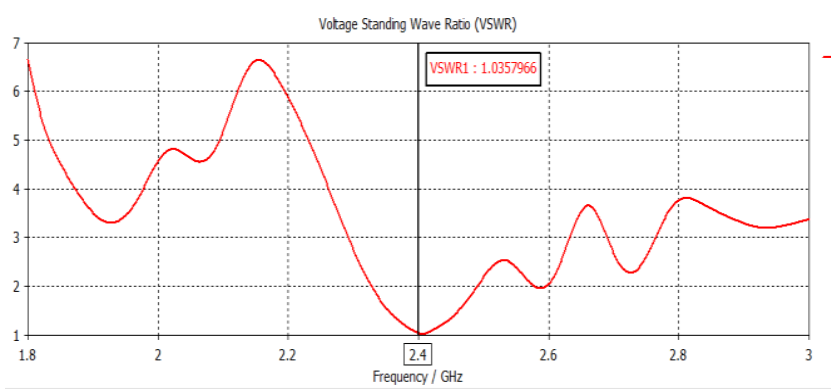

Fig. 12. VSWR Simulation Results of 4x1 Array Microstrip Antenna

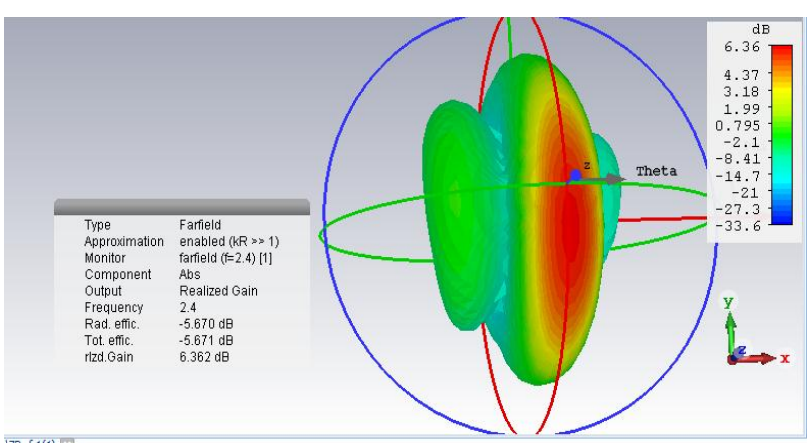

Fig. 13. Gain Simulation Results of $4 \times 1$ Array Microstrip Antenna 


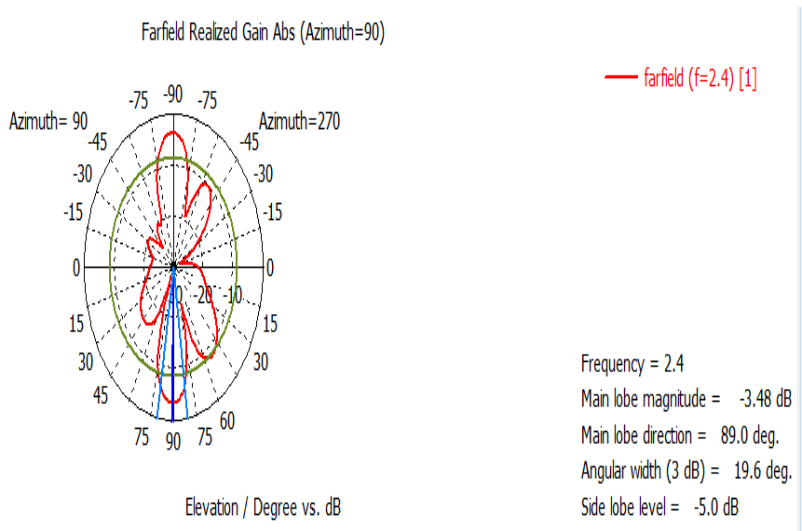

Fig. 14. . Results of Simulation of 4x1 Array Microstrip Antenna Radiation Patterns

\section{2) Fabrication Results Of $4 x 1$ Array Microstrip}

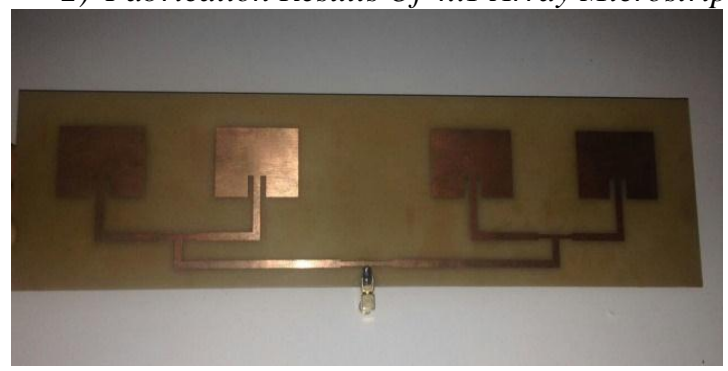

Fig. 15. 4x1 Array Microstrip Antenna Patch

Fig 15, showed result of $4 \times 1$ array microstrip antenna using two layers circuid board.

\section{3) Testing with VNA}

The $4 \times 1$ fabricated microstrip array antenna is able to work at $2.4 \mathrm{GHz}$ with return loss $=-19.41 \mathrm{~dB}$, VSWR $=1.235$, impedance $=54.77 \square \square 10,750$. This means that the antenna that is fabricated is in accordance with the expected specifications. For its impedance it almost matches the impedance of the RG58 $50 \square$ coaxial cable.

Bandwidth of $90 \mathrm{MHz}$ between the frequency of $2.328 \mathrm{GHz}$ $-2.418 \mathrm{GHz}$. Test results with VNA are shown in the following Fig 16-18.

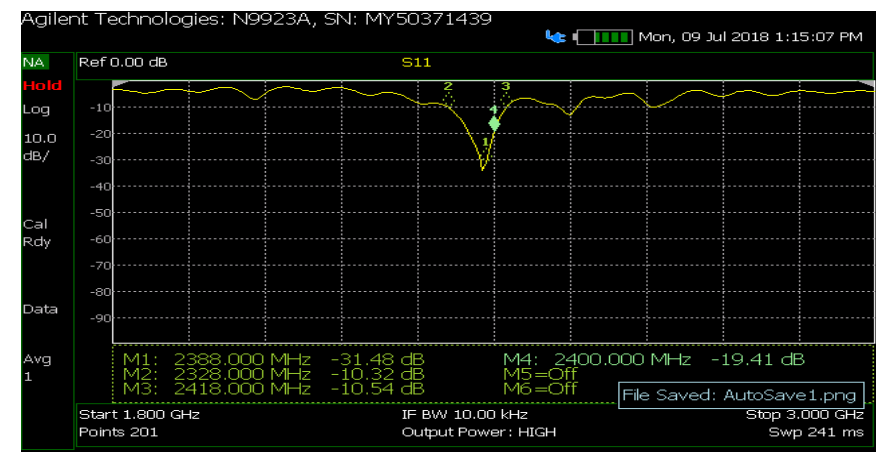

Fig. 16. . Results of Return Loss Testing with VNA in 4x1 Array Microstrip Antenna

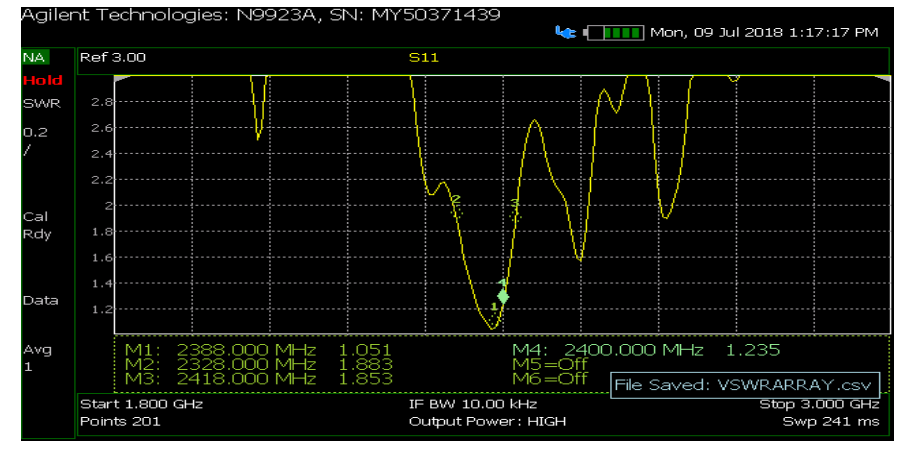

Fig. 17. Results of VSWR Testing with VNA in 4x1 Array Microstrip Antenna

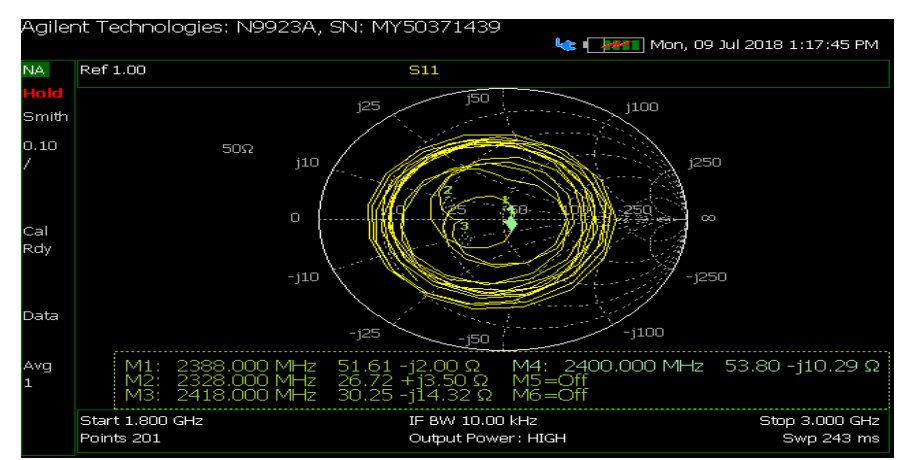

Fig. 18. Results of Impedance Testing with VNA in 4x1 Array Microstrip Antenna

\section{CONCLUSION}

This research obtained to designed, simulation, fabrication, antenna parameter testing using VNA (Vector Network Analyzer). The conclusions that can be taken from this research are:

1. From simulation showed the sending microstrip antenna that is manufactured according to the expected specifications. the antenna is able to work at a frequency of $2.4 \mathrm{GHz}$ with return loss $=-12.06 \mathrm{db}$, VSWR $=1.692$, impedance $=38.35 \mathrm{ohms}$. It is as desired that antenna work at $2,4 \mathrm{GHz}$ frequency.

2. Design of $4 \times 1$ array microstrip antenna fabricated is also in accordance with the expected specifications. From simulaton showed that antenna is able to work well at a frequency of $2.4 \mathrm{GHz}$ with return loss $=-19.41 \mathrm{db}, \mathrm{VSWR}=1.235$, impedance $=54.77 \mathrm{ohms}$.

3. Data communication testing in sending and receiving data has been successfully carried out on both antennas that have the same frequency of $2.4 \mathrm{GHz}$, where as sender was microstrip antenna and 4x1 array microstrip as received antenna.

\section{ACKNOWLEDGMENT}

Alhamdulillahi rabil 'alamin, the researcher expresses his highest gratitude to Allah subhanahu wa ta'ala for blessing, love, opportunity, health, and mercy to complete this paper. Also to Ms. Silvi and Mr. Haryanto as part as team. Thanks to FT crew Dean, Mr. Yasid, Mr. Wahyudi, Mr. Yusuf and other that I can not mention all. 


\section{REFERENCES}

[1] B. P. Lapanporo, "Prototipe Sistem Telemetri Berbasis Sensor Suhu dan Sensor Asap untuk Pemantau Kebakaran Lahan [Telemetry System Prototype Based on Temperature Sensors and Smoke Sensors for Land Fire Monitoring]", POSITRON, 2011.

[2] A. B. Constantine, "Antenna Theory: Analysis and Design", USA: John Willey and Sons, 2005.

[3] S. Alam, I. G. N. Y. Wibisana, and I. Surjati, "Rancang Bangun Antenna Mikrostrip Peripheral Slits Linear Array Untuk Aplikasi Wi-Fi [Building Design of Peripheral Microstrip Antenna Linear Array for Wi-Fi Applications \}," J. Rekayasa Elektrika, vol. 13, no. 1, pp. 18-26, 2017.

[4] D. Pasaribu, A. H. Rambe, "Rancang Bangun Antena Mikrostrip Patch Segiempat Pada Frekuensi 2, 4 Ghz Dengan Metode Pencatuan Inset [Design of Patch Rectangular Microstrip Antenna at Frequency of 2, 4 Ghz with the Inset Imaging Method] ", SINGUDA ENSIKOM, 2014.

[5] K. Joni, R. Hidayat, dan S. Sumaryono, "Pengujian Jarak dan Waktu Gabung Protokol IEEE 802.15. 4 / ZigBee di Lingkungan Indoor [Protocol IEEE 802.15. 4 / ZigBee Distance Test and Join Time in the Indoor Environmentl], JNTETI, vol. 1. no. 2, 2012.

[6] Nurbani, Y. S. Rohmah, \& D. A. Nurmantris, "Realisasi Antena Mikrosrip Sistem Aerial Video Pada Sisi Ground Segment Di Frekuensi $5.8 \mathrm{Ghz}$ [The Realization of Aerial System Microscope Antennas on the Ground Segment Side at 5,8 Ghz Frequency]", Jurnal Elektro Telekomunikasi, 2017.

[7] W. Cahyadi dan Ardiyansyah, "Rancang Bangun Antena Mikrostrip Meander-Line 915 MH z untuk Optimasi Jarak Pengiriman Data Alat Ukur Ph Meter Sistem Telemetri [Design of 915 MH Meander-Line Microstrip Antenna for Optimization of Data Transmission Distance for Telemetry Systems]", Jurnal Rekayasa Elektrika vol, 13, no. 2, 2017.

[8] R. A. Gusma, Y. Rahayu, \& L. O. Sari, "Simulasi Antena Mikrostrip Patch Persegi Panjang Planar Array 6 Elemen Dengan Pencatuan Aperture Coupled Untuk Aplikasi CPE WiMAX Pada Frekuensi 3, 3-3, 4 $\mathrm{GHz}$ [Microstrip Antenna Simulation of Planar Array Rectangular Patches 6 Elements With Shaping Aperture Coupled For CPE WiMAX
Applications At 3, 3-3, 4 GHz Frequency]", Jurnal Online Mahasiswa (JOM) Bidang Teknik dan Sains, vol. 1, no. 2, pp. 1-9, 2014

[9] D. Qun, J. J. weiwiangZhang, “ Design and simulation of the microstrip antenna for 2,4 GHz HM remote Control System", 2nd conference on System Engineering and modelling (ISCEM-13), Atlantis Press, Paris, France, 2013. 